\title{
Customer Service Quality Management in Public Transport: The Case of Rail Transport in Tanzania
}

\author{
LWESYA Francis ${ }^{27}$, JAFFU Richard ${ }^{28}$
}

\begin{abstract}
The main objective of the study was to assess customer service quality management by taking into account the factors affecting the service quality in rail transport sector. To achieve the study objectives, we use descriptive statistics and regression analysis. We adopted a dual pronged view of internal customers (employees) and external customers (clients) by focusing on the skills and qualifications of customer contact personnel in service encounters, incentives, staff training, working tools and other operational facilities. For the case of external customers, quality service dimensions as synthesized in SERVQUAL model were used.

The results show that customers' expectations of service quality are accurately predicted by service providers along each of the service quality dimensions except the reliability dimension.

This shows that there is a gap between service delivered and external communication of rail transport services and this difference is related to the performance of the promised service accurately and dependably. This gap seemed to be attributed to by the shortage of working tools, aging equipments and other operational facilities on the part of customer contact personnel thereby distracting clients in assessing rail transport services and thus creating the difference on what is expected by clients and what is really provided by service providers.

Thus, the study recommends incorporating total quality management in the delivery of rail transport services. Working tools and other operational facilities should be provided to employees in order to enhance performance and job satisfaction. Employees particularly the customer contact personnel should be regularly trained to keep them abreast with current trends in clients handling techniques consistent to meeting their requirements and wants. Drawing lessons from other competitors like what is happening in road transport or air transport will help setting quality standards.
\end{abstract}

Keywords: Customer Service Quality Management, Quality Service, SERVQUAL, Quality Gap

JEL: M10, L10, L80

UDK: 005.336.3:656.222(678)

005.346

COBISS.SR-ID 253511948

\section{Introduction}

Today due to embracing globalization and trade liberalization policies in the world, the business environment has become more competitive. Customers on the other hand are more

\footnotetext{
${ }^{27}$ Department of Business Administration, School of Business Studies and Economics, University of Dodoma, Tanzania, flwesya@yahoo.com

${ }^{28}$ Department of Business Administration, School of Business Studies and Economics, University of Dodoma, Tanzania
} 
alert and conscious of the prevailing business environment; as a result, they tend to prioritize quality in determining where to acquire a certain service or where a certain product is to be bought. This in turn has necessitated putting quality at the centre in the delivery of services in both public and private organizations. However, according to Anable (2005) and Oliver (1981), many public-sector organizations including transportation services are created by governments with an intention not to compete in the open market, instead their objective is to fulfill the needs of the common public. In contrast to this earlier view, Behwal (2010) and Dridi et al., (2005) argue that public transport services, must follow regular schedules, be safe and rapid, guarantee high service quality, utilize resources efficiently and meet users' need. Thus, in order to keep and attract more customers and fulfill their needs, public transport must have high service quality to satisfy and meet a wider range of customers' needs. Nashappi et al., (2014), state that service providers who are unable to effectively cater to the needs and wants of customers, are risking not only by losing dissatisfied customers to competitors, but also an ultimate erosion of profits and consequently failure.

Rail transport can be one of the most reliable means of transportation for both passengers and traffic in developing countries. This is because it is relatively cheaper, convenient and can cater the needs of the poor people. According to African Development Bank report (2015), rail transport as a result of its energy efficiency, reduced greenhouse gas emissions and lower cost per ton kilometer, is expected to play an increasingly important role in the conveyance of freight over long distances. In comparison to other means of transportation, railways are particularly useful in mass transit systems for both inter-city and urban settings. Olievschi (2013) argues that increasing the volumes of traffic is not sufficient to make a railway system financially viable, it is also necessary to make it competitive. This means providing quality transport services (price, speed, availability, punctuality, etc) which are ultimately superior to the competition; only then can railway systems become an attractive option for shifting part of the existing road traffic to rail, or for putting on rail the new volumes of freight generated by the economic development of the countries.

Tanzania enjoys two forms of railway transport systems with a total of 3676 kilometers of railway lines. One is run jointly between Tanzania and Zambia (Tanzania and Zambia Railway Authority-TAZARA) and the other one is owned and run by United Republic of Tanzania, namely the Tanzania Railway Corporation (TRC). TAZARA line is 1860 kilometers in length, of which 975 kilometers is in Tanzania and 885 kilometers in Zambia. It is handling cargo for the countries of Malawi, Zambia, Zimbabwe and Democratic Republic of Congo. The mainline of TRC comprises the central corridor between the port of Dar-Es-salaam in the east, linking central and western areas of the country and terminating at Kigoma on Lake Tanganyika in the west. It handles cargo for landlocked countries of Burundi, Rwanda, and eastern part of People's Republic of Congo. Railway transport is the second most important mode of transport after road and is critical for long distance freight along the main transport corridors. However, recently the performance of railway transport has not been impressive and since railway transport is run by government organizations in many developing countries, there are concerns over neglecting the concept of total quality management in their day to day operations, a factor which to some extent deters clients from using railway transportation systems. Therefore, this paper is set to take stock the services offered by railway transport in light of customer service quality management and fills the study gap that exists in Tanzania.

\section{Objectives of the Study}

The overall objective of the study is to assess customer service quality management in public transport. The specific objectives of the study were:

1. To examine the customer service satisfaction or dissatisfaction

2. To assess quality management systems 
3. To determine the problems facing rail transport customers

\section{Research Questions}

1. What factors are responsible for quality service shortfalls?

2. What is the gap between customer expectations and management perception of customers' expectation?

3. Are service quality specifications different from the actual service delivered?

\section{Research Hypothesis}

- $\mathrm{H}_{0}=$ There is no positive relationship between service quality dimensions and client's satisfaction

- $\mathrm{H}_{1}=$ There is a positive relationship between service quality dimensions and client's satisfaction

\section{Literature Review}

Service have been defined as originally intangible and relatively quickly perishable activities whose buying take place in an interaction process aimed at creating customer satisfaction but during this interactive consumption this does not always lead to material possession (Kasper et al., 1990). Ramaswamy (1996), described service as business transactions that take place between a donor (services provider) and receiver (customer) in order to produce an outcome that satisfies the customers. While Gronroos (1990), pointed out that a service is an activity or series of activities of more or less intangible nature that normally, but not necessary, take place in interaction between customer and service employees and or service provider, which are provided as solutions to customer problems. On the other hand, Lahtinem (1983) defines service quality as a result from a comparison of what customer feel service provider should offer (expectation) with provider actual performance. Parasiraman, Zeitham, and Berry (1985) viewed quality as the degree and direction of discrepancy between customers' services perception and expectations while Denton (1996:91) defines service quality, as a one, which is measured by the different between the expectation of customer and customer perceived level of service delivered.

Provision of quality service to customers has become of focus of many organizations. Customer satisfaction is recognized as being of paramount importance for the existence of any organization. Eboli and Mazulla (2007) investigated service quality attributes important for customer satisfaction with a bus transit service in Cosenza, Italia. According to them, respondent was asked to rate the importance and satisfaction with 16 service quality attributes (bus stop availability, route characteristic, frequency, reliability, bus stop furniture, bus overcrowding, cleanliness, cost, information, promotion, safety on board (drivers character), personal security, personnel, complains and its handling, environmental protection and bus stop maintenance). According to the result of the research customers' satisfaction is closely related with transport service planning which is reflected in reliability, frequency, information, promotion, personnel and complaint. Rasheed (2016), states that excellent service affects the retention of existing customers and inducement of new customers. As a result, it brings high customer retention and satisfaction that helps them for sustainable development of the company. Traditionally, the performance indicators for public transport are divided into two categories: efficiency and effectiveness. Under the efficiency category, the measures are concerned with the process that produce the services while the effectiveness category are used to determine how well the services provided are with respect to the objectives that are set for them (Pullen,1993). William and James (1995) in understanding service management discussed 
the benefits of customer care by saying that with a focus on customer care organization can expect a number of benefits, which are:

- Customer loyalty through satisfaction. Look after present customers can generate attraction of few customers through positive word of mouth communication, Customer retention is more cost effective than trying to attract new customers cost savings also accrue from getting things right at the first time (Glynn. 1995:60)

- Increased opportunities for cross selling. Comprehensive and up to date product knowledge and sales techniques among employees, combined with developing relationship and rapport with customers, enables staff to identity customer needs and suggest relevant product/service.

- Employee benefit which may be seen in terms of job satisfaction and moral and commitment to the company, successful employee/employer relationships and increased staff royalty which contribute to reducing the rate of staff turnover and associated costs of recruitment selection and train activities. Committed and competent employees will also make fewer mistakes and in turn lead to fewer customer complaints and so contribute to further cost saving.

\section{Dimensions of Service Quality}

To understand service quality, there is an array of factors or determinants. A number of researchers have provided lists of quality determinants. Parasuraman et al., (1985), in their research confirmed that both outcome and process dimensions influence customers' evaluation of service quality. The common pattern of response from the focus group interviews revealed 10 key evaluation criteria that customers might use, regardless of the type of service sector. The following are the set of service quality dimensions.

1. Tangible, Are the appearance of the physical facilities, equipment personnel and communication personnel

2. Reliability, Is the ability to perform the promised service dependably and accurately

3. Responsiveness, Are the willingness to help the customers and provide prompt service.

4. Competence, Possession of the required skill and knowledge of contact personnel.

5. Courtesy, Politeness, respect, consideration friendliness of contact personnel.

6. Credibility, Trustworthiness, believability and honesty.

7. Security, Freedom from dangers, risk or doubt.

8. Access, Approachability and easy of contact.

9. Communication, keeping customer informed in the language they understand listen to them.

10. Understanding the customer, making the effort to the customer and their needs.

However, the best-known determinants emanate from Parasuraman and colleagues from USA, who found five dimensions of service quality namely Tangibles, Reliability, Responsiveness, Assurance and Empathy and used these as the basis for their service quality measurement instrument, SERVQUAL (Parasuraman et al., 1988; Zeithaml et al., 1990).

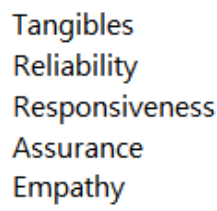

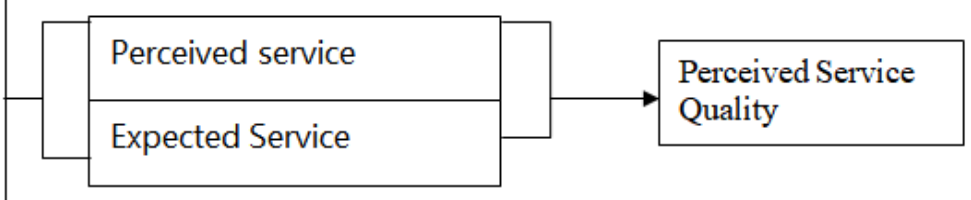

Fig. 1. Dimensions of Service Quality Source: Adapted from Parasuraman et al. (1988) 


\section{Service Quality Gap}

Quality of service is measured by difference between expectations of the customer on the one hand and the customer perceived level of service delivered on the other hand, the gap between two points represents the size of service problem. Feedback from the customer is necessary for maintaining or improving the quality of service being delivered. Deviation or service problem could occur because of the following reasons;

- Service standard may be too high to be achieved, in which case the standards need to be changed.

- The personnel may not be in position to deliver the required service because they were not trained properly. If the front-line service provided are not properly trained or qualified to do the job then the service performance standard cannot be met.

- It could be the neglect of service provider, it is possible to train and motivate service providers.

- Could occur because the service provider could notify too late about the services needed by customer.

Kotler (1997) identified five gaps of service quality that cause unsuccessful service delivery, these are;

- A gap between the customer expectation and management perceptions. Here management does not always receive correctly what customer want.

- A gap between management perception and service quality specification. Here management might correctly perceive the customer want but do not set specific performance standards.

- A gap between service quality specification and actual service delivered. Here the personnel might be poorly trained or incapable of, or unwilling to meet the standard or they may be held to conflicting standards.

- A gap between perceived service and expected service. This gap occurs when customer misperceives quality.

In order to address quality service gaps in a company/organization, internal marketing is key. Internal marketing signifies the work done by the company to train and motivate the employees to save the customers. The company must treat the employees as the first customers by training the so as to be able and willing to deliver desired level of service to their external customers. Also, organization should carry out research among employees to identify their needs and attitude with respect to working conditions benefits and company policies this research will motivate the employees by giving them rewards and fringe benefits i.e. cafeteria benefit, health insurance, pension, housing etc. This means, satisfying the needs of internal customers upgrade the capability to satisfy the needs of external customers. Groonroos (1985), outlined three objectives of internal marketing which are as follows;

- Overall - To achieve motivated customer conscious and care oriented personnel

- Strategies - To create an internal environment that supports customer consciousness and sales mindless among personnel

- Tactical - To sale service campaigns and marketing phase efforts of the company via staff training programs and seminars

\section{Managing Service Quality}

Kotel (1991:463) states that one of the major ways to differentiate a service firm is to deliver consistently higher quality service than competitors. The key is to meet or exceed the target customer service quality expectations. Customer satisfaction are formed by their past experiences, word of mouth and service firm advertising. The customer chooses service provider on this base and after receiving the service compare the perceived service with 
expected service. If the perceived service falls below the expected service, customers lose interest in the provider. As a result, companies find that effectively handling customers with problem is critical to their reputations as well as their bottom lines. When customer complains and they are satisfied with the way their complaints are handled, they are more likely to purchase another product or service from the same company. Kotler P (1997:481), States that studies of customer dissatisfaction show that customer are dissatisfied with their purchases about $25 \%$ of the time, only $5 \%$ complain and the rest either feel that is not worth to complain or that they do not know to whom to complain. For all these reasons companies should need to develop a service recovery program. As a first step, companies should make easy for dissatisfied and complain. They should provide suggestions and complaints form. Second, the company should empower the employees. Employees who receive complaints must be trained and empowered to resolve customer problems speedily and satisfactorily. Studies show that the faster the company responds to the complaints, the higher the customers' satisfaction with the company. Third the company should go beyond satisfying particular customers to discovering and correcting the roots cause of the frequent problems. By studying the Patten of complaints, the company can correct system failures that give raise to these complaints.

\section{Methodology}

This study uses descriptive statistics and regression analysis. To achieve the study objectives, we make internal and external customers analyses. The analysis of internal customers dwelt on the skills and qualifications of customer contact personnel in service encounters, incentives, staff training, working tools and other operational facilities. On the other hand, the basis of analysis for external customers was quality service dimensions as synthesized in SERVQUAL model (Parasuraman et al., 1988; Zeithaml et al., 1990). Several studies have provided evidence on the superiority of SERVQUAL model over others as Carrillat et al., (2007) suggested that both scales (i.e., SERVPERF and SERVQUAL) are adequate and equally valid predictors of overall service quality. However, the authors believe that the SERVQUAL scale could be of greater interest for practitioners due to its richer diagnostic value (i.e., comparing customer expectations of service versus perceived service across dimensions). Also, the results of the study revealed that the need to adapt the measure to the context of the study in the case of SERVPERF is less than in the case of SERVQUAL. It is from these views that this study uses SERVQUAL model to assess customer service quality management in public transport. In light of the quality service dimensions, rail transport services were evaluated in the following perspective.

Table 1. Dimensions of Service Quality

\begin{tabular}{|c|c|c|}
\hline N0 & Dimension & Measurement \\
\hline \multirow[t]{4}{*}{1.0} & \multirow{4}{*}{$\begin{array}{l}\text { Tangible. The appearance of the } \\
\text { physical facilities, equipment, } \\
\text { personnel and communication } \\
\text { materials are summarized here as } \\
\text { under, }\end{array}$} & $\begin{array}{l}\text { Physical facilities include station buildings wagons } \\
\text { passenger coaches, which are supposed to be physical } \\
\text { appealing and cleaned to reflect good ambient/ } \\
\text { surroundings. }\end{array}$ \\
\hline & & $\begin{array}{l}\text { Equipment include computerized freight services, the } \\
\text { computerized advance cargo information system used for } \\
\text { the tracking the movement of wagons and consignment. }\end{array}$ \\
\hline & & $\begin{array}{l}\text { The contact personnel must be credible, trustworthy, and } \\
\text { friendly and dressed appropriately. }\end{array}$ \\
\hline & & $\begin{array}{l}\text { Communication tools should be operational i.e. in good } \\
\text { working condition; these are rail track (way), Radio calls, } \\
\text { Telephone, fax and internet to simplify communication }\end{array}$ \\
\hline \multirow[t]{3}{*}{2.0} & \multirow{3}{*}{$\begin{array}{l}\text { Reliability dimension - This is the } \\
\text { ability to perform the promised } \\
\text { service dependably and accurately, } \\
\text { it means to perform service right the }\end{array}$} & $\begin{array}{l}\text { Supply of empty wagon for loading correct quantity, } \\
\text { suitable type and observing punctuality. }\end{array}$ \\
\hline & & Removal of wagons as quickly as possible after loading. \\
\hline & & Movement of goods and \\
\hline
\end{tabular}




\begin{tabular}{|c|c|c|}
\hline & nd the firm's honor of its & to its destination station, comfortably, safely and on time \\
\hline & & Punctual placement of loaded wagons at destination \\
\hline & & Timely removal of empty wagons after loading \\
\hline & & $\begin{array}{l}\text { Conforming to movement schedules and giving notice to } \\
\text { customers during changes }\end{array}$ \\
\hline 3.0 & $\begin{array}{l}\text { Responsiveness - The willingness, } \\
\text { readiness of employees to help } \\
\text { customer and provision of prompt } \\
\text { service. It involves responding } \\
\text { immediately to customer requests, } \\
\text { processing document immediately, } \\
\text { calling customers quickly and } \\
\text { setting up appointments quickly. }\end{array}$ & $\begin{array}{l}\text { Customer contact personnel includes booking clerks, chief } \\
\text { book clerk, delivery clerks, luggage clerks, station } \\
\text { masters, commercial inspectors, coach attendants, potters, } \\
\text { hostesses, non-operation staff like police etc. Customers } \\
\text { expect that whenever they face a problem during a service } \\
\text { encounter the customer contact personnel will be willing } \\
\text { to help and solve the problem as quickly as possible. }\end{array}$ \\
\hline 4.0 & $\begin{array}{l}\text { Assurance - This is the confidence } \\
\text { relief and ability to build up in the } \\
\text { mind of the customer by customer }\end{array}$ & $\begin{array}{l}\text { Courtesy, politeness, respect and friendliness of customer } \\
\text { contact personnel }\end{array}$ \\
\hline & contact personnel during service & Credibility, honest and trustworthiness \\
\hline & $\begin{array}{l}\text { person to perform job and the } \\
\text { customer are in the safe hands in } \\
\text { term of competence (possession of } \\
\text { the required skills and knowledge) }\end{array}$ & $\begin{array}{l}\text { Security, how security of passengers and parcels is } \\
\text { ensured, cargo security at the stations, while in transit, } \\
\text { loading and off-loading security }\end{array}$ \\
\hline 5.0 & $\begin{array}{l}\text { Empathy - This also include } \\
\text { provision of caring and } \\
\text { individualized attention to customer } \\
\text { needs and requirements }\end{array}$ & $\begin{array}{l}\text { Easy accessibility of customer to service. Letting the } \\
\text { customer know the services available and telling so far } \\
\text { what can be provided to meet the requirements. E.g. } \\
\text { freight customer may need to use covered wagon or tank } \\
\text { wagon depending on the nature of goods, need to be } \\
\text { provided with information on the service available }\end{array}$ \\
\hline & & $\begin{array}{l}\text { Communication, telling customer in the language they } \\
\text { understand and listening them their requirements }\end{array}$ \\
\hline
\end{tabular}

\section{Study Findings}

\section{Distribution of the Respondents}

A sample size of 182 customers were consulted and interviewed. This includes 46 internal customers which comprised of employees at management level, customer contact personnel in service encounters, Service support employees and non-operation employees and 136 were external customers. In collection data purposive sampling and stratified random sampling were used.

Table 1. Employees' Gender and level of Education

\begin{tabular}{||l|l|l||}
\hline Qualifications & People & Percentage \\
\hline Gender & 24 & $52 \%$ \\
\hline Male & 22 & $48 \%$ \\
\hline Female & 11 & $23.91 \%$ \\
\hline Graduate/Advanced Diploma & 22 & $47.83 \%$ \\
\hline Ordinary Diploma & 13 & $28.26 \%$ \\
\hline Secondary education & - & \\
\hline Primary education & \multicolumn{2}{|l|}{} \\
\hline
\end{tabular}

Table 1 above shows that $52 \%$ of the employees were male and $48 \%$ were female.

Regarding the level of education, $28.26 \%$ of the employees attended secondary education, $47.83 \%$ had ordinary diploma, while $23.91 \%$ have advanced diploma or are university graduates. According to the above findings, it shows that more than $50 \%$ of the employees particularly front-line staff who meets face to face with customers have substantial knowledge 
which relevant in providing good service to customers. This includes booking clerks, delivery clerks, station masters, commercial inspectors, coach attendants, luggage clerks, train conductors and information desktop. In analyzing the perceptions of internal customers, the paper uses descriptive statistics. Coefficient of variation is used to measure the dispersion of data points in a data series around the mean. It is a useful statistic for comparing the degree of variation from one data series to another. It is calculated by Standard Deviation/Mean.

Table 2. Perceptions of the Employees

\begin{tabular}{|c|c|c|c|c|}
\hline No & Item & Mean & $\begin{array}{l}\text { Standard } \\
\text { Deviation } \\
\end{array}$ & $\begin{array}{l}\text { Coefficient of } \\
\text { Variation }\end{array}$ \\
\hline 1.0 & $\begin{array}{l}\text { The employees cooperate among departments and } \\
\text { within departments, each department really links with } \\
\text { the other departments on issues that are affecting the } \\
\text { organization; managers are working and listening to } \\
\text { other managers, which lead to sharing problems and } \\
\text { solutions }\end{array}$ & 3.8043 & 1.10794 & $29 \%$ \\
\hline 2.0 & $\begin{array}{l}\text { The management is offering employees incentives and } \\
\text { are given in form of free houses; leave benefits, medical } \\
\text { facilities when become sick, transport assistance is } \\
\text { provided to them, education relief and meals } \\
\text { allowances }\end{array}$ & 3.7391 & 1.10423 & $29.5 \%$ \\
\hline 3.0 & $\begin{array}{l}\text { We are given training in order to equip us in day to day } \\
\text { activities in form of courses and seminars in areas like } \\
\text { management, marketing and traffic, commercial } \\
\text { inspection etc and the training given improve our } \\
\text { customer service knowledge and feel well trained to } \\
\text { interact with customers }\end{array}$ & 3.5217 & 1.18770 & $33.7 \%$ \\
\hline 4.0 & $\begin{array}{l}\text { We have enough working tools necessary for customer } \\
\text { service, tools like gentry cranes for goods handling, } \\
\text { computers for keeping customers information, and } \\
\text { parcel weight measuring equipments }\end{array}$ & 2.8478 & 1.24664 & $43.78 \%$ \\
\hline 5.0 & $\begin{array}{l}\text { We often interact with our clients to understand their } \\
\text { satisfaction with the services offered }\end{array}$ & 4.0435 & 0.94178 & $25.9 \%$ \\
\hline 6.0 & $\begin{array}{l}\text { clients are following rules and regulations and comply } \\
\text { with terms set by the organization to avoid unnecessary } \\
\text { problems }\end{array}$ & 3.8696 & 1.00241 & $25.9 \%$ \\
\hline 7.0 & $\begin{array}{l}\text { Service providers are keeping its promises to customer } \\
\text { satisfactorily }\end{array}$ & 4.0870 & 0.78390 & $19.18 \%$ \\
\hline 8.0 & Employees feel satisfied with the jobs they perform & 3.8043 & 0.93380 & $24.5 \%$ \\
\hline 9.0 & $\begin{array}{l}\text { The employees have substantial knowledge on the } \\
\text { works they perform (technical know-how) }\end{array}$ & 3.1957 & 1.36006 & $42.6 \%$ \\
\hline 10 & $\begin{array}{l}\text { Good supervision is the means of good performance } \\
\text { evaluation and that does not cause shortfalls in actual } \\
\text { service performance }\end{array}$ & 3.9348 & 1.06254 & $27 \%$ \\
\hline 11 & $\begin{array}{l}\text { Horizontal communication leads to improved service } \\
\text { performance. This because customer contact personnel } \\
\text { might have instructions from their supervisor on how to } \\
\text { carry certain functions and these instructions are not } \\
\text { meant to conflict with customer demands }\end{array}$ & 3.8043 & 1.20406 & $31.6 \%$ \\
\hline 12 & $\begin{array}{l}\text { External communication does not contribute to quality } \\
\text { service shortfalls. This is because communication made } \\
\text { to customers raises their expectations about the service } \\
\text { provision, the external communication made to } \\
\text { customers through advertisements, promotional } \\
\text { brochures and promises help in creating awareness to } \\
\text { customers of what is being provided. }\end{array}$ & 4.0652 & 0.77179 & $19 \%$ \\
\hline
\end{tabular}


Table 2 shows the perceptions of employees. The employees gave varied opinions. In terms of the cooperation among employees, this item had $3.8043(76 \%)$ mean and the views of the employees in this component were consistent with coefficient of variation of $29 \%$. This suggests that cooperation among departments and within departments is good, each department really links with the other departments on issues that are affecting the organization; managers are working and listening to other managers, which lead to sharing problems and solutions. In terms of provision of incentives, the employees agreed that the management is offering incentives in form of free houses; leave benefits, medical facilities when become sick, transport assistance, education relief and meals allowances. The views expressed had the mean of 3.7391 (74\%) and were consistent with the coefficient of variation of $29.5 \%$. Regarding training, the employees agreed that are given training in order to equip them in day to day activities in form of courses and seminars in areas like management, marketing and traffic, commercial inspection etc, also customer contact personnel are given training to improve their customer service knowledge and feel well trained to interact with customers. However, regarding the working tools, this item had the lowest mean of 2.8478 (59.9\%) and the views were consistent with a coefficient of variation of $43.78 \%$. This suggests that employees do not have enough working tools such as computers, loading equipments, motor vehicles and there exists a problem of ageing equipments and other operational facilities. Lack of sufficient working tools and the tendency of relying on aged equipments may lead to services being provided to become substandard thereby inhibiting promptness and effectiveness in the delivery of services. In terms of the interaction with customers, the employees agreed that they interact with customers.

This item had relatively higher mean of $4.0435(80.9 \%)$ and the views were consistent by $25.9 \%$ coefficient of variation.

Table 3. Distribution of the Respondents

\begin{tabular}{||l|l|l||}
\hline Item & People & Percentage \\
\hline Gender & & \\
\hline Male & 84 & 61.8 \\
\hline Female & $\mathbf{5 2}$ & 38.2 \\
\hline Graduate/Advanced Diploma & & \\
\hline Ordinary Diploma & 22 & 16 \\
\hline Secondary Education & 33 & 24 \\
\hline Primary Education & 54 & 39.7 \\
\hline Age of the respondents & 28 & 20.6 \\
\hline $18-30$ & & \\
\hline $31-40$ & 22 & 16 \\
\hline $41-50$ & 38 & 27.9 \\
\hline $51-65$ & 40 & 29.4 \\
\hline$>66$ & 15 & 11 \\
\hline Occupation & 21 & 15 \\
\hline Civil/public & & \\
\hline Student & 33 & 24 \\
\hline Business man & 21 & 15 \\
\hline Others & 58 & 42.6 \\
\hline Monthly Income (Tanzania Shillings) & 24 & 17.6 \\
\hline$<200,000$ & 20 & \\
\hline $201,000-400,000$ & 22 & 14.7 \\
\hline $401,000-600,000$ & 25 & 16 \\
\hline $601,000-800,000$ & 21 & 15 \\
\hline $801,000-1000,000$ & 18 & 13 \\
\hline$>1,001,000$ & 30 & 22 \\
\hline Total & 136 & $100 \%$ \\
\hline & & \\
\hline & $2017)$ \\
\hline
\end{tabular}

Source: Field Survey (2017) 
Of the total 136, respondents $84(61.8 \%)$ were male and 52(38.2\%) were female (Ttable 1$)$.

Age wise, 41 to 50 years $(29.4 \%)$ a group with the most respondents, followed by those between 31 to 40 years $(27.9 \%)$. Respondents between 18 to 30 years were $22(16 \%)$ and the relatively lower number of respondents was between 55 to 65 years $(11 \%)$. This suggests that most of the external clients who use rail transport services are below 50 years of age. The age that is quite sensitive in terms of the kind and quality of services being provided. In terms of the level of education most of the respondents had secondary education $(39.7 \%)$, followed by those who had diploma education (24\%). Respondents who had university education were $(16 \%)$ and those who had the least education were the primary school education holders $(20.6 \%)$. This suggests that most of the respondents had at least formal education which shows that most of the respondents could make rational decision.

In terms of the reliability test for the dimension, the items yielded a Cronbach's alpha from 0.807 to 0.816 which is above the minimum threshold level of 0.60. Bush et al., (2006) suggest a Cronbach's alpha valued at less than 0.6 as unsatisfactory. According to Msabila and Nalaila (2013), reliability has to do with quality of measurement i.e consistency or repeatability of your measures (table 4).

Table 4. Reliability Test Results

\begin{tabular}{||c|c|c|}
\hline \multicolumn{1}{|c|}{$\begin{array}{c}\text { Multi-Item Scale } \\
\text { (Dimensions) }\end{array}$} & Cronbach's Alpha & Number of Items \\
\hline Tangible & 0.816 & 4 \\
\hline Reliability & 0.815 & 6 \\
\hline Responsiveness & 0.807 & 1 \\
\hline Assurance & 0.816 & 3 \\
\hline Emphathy & 0.812 & 2 \\
\hline
\end{tabular}

Table 5. Results based on Dimensions of Service Quality Assessment

\begin{tabular}{|c|c|c|c|c|c|c|}
\hline N0 & Dimension & Measurement & Mean & $\begin{array}{l}\text { Std } \\
\text { Dev }\end{array}$ & $\begin{array}{l}\text { Average } \\
\text { Mean }\end{array}$ & $\begin{array}{l}\text { Average } \\
\text { Std }\end{array}$ \\
\hline \multirow[t]{4}{*}{1.0} & \multirow[t]{4}{*}{ Tangible } & $\begin{array}{l}\text { Physical facilities include station } \\
\text { buildings wagons passenger } \\
\text { coaches, which are supposed to be } \\
\text { physical appealing and cleaned to } \\
\text { reflect good ambient/surroundings. }\end{array}$ & 3.7353 & 1.0344 & \multirow{4}{*}{3.9448} & \multirow{4}{*}{0.8979} \\
\hline & & $\begin{array}{l}\text { Equipment include computerized } \\
\text { freight services, the computerized } \\
\text { advance cargo information system } \\
\text { used for the tracking the movement } \\
\text { of wagons and consignment. }\end{array}$ & 4.0441 & 0.8061 & & \\
\hline & & $\begin{array}{l}\text { The contact personnel must be } \\
\text { credible, trustworthy, and friendly } \\
\text { and dressed appropriately. }\end{array}$ & 3.8750 & 0.9770 & & \\
\hline & & $\begin{array}{l}\text { Communication tools should be } \\
\text { operational i.e. in good working } \\
\text { condition; these are rail track (way), } \\
\text { Radio calls, Telephone, fax and } \\
\text { internet to simplify communication }\end{array}$ & 4.1250 & 0.7740 & & \\
\hline \multirow[t]{3}{*}{2.0} & \multirow[t]{3}{*}{$\begin{array}{l}\text { Reliability } \\
\text { dimension }\end{array}$} & $\begin{array}{l}\text { Supply of empty wagon for loading } \\
\text { correct quantity, suitable type and } \\
\text { observing punctuality }\end{array}$ & 3.0221 & 1.8072 & \multirow{3}{*}{3.31618} & \multirow{3}{*}{3.1943} \\
\hline & & $\begin{array}{l}\text { Removal of wagons as quickly as } \\
\text { possible after loading }\end{array}$ & 3.0074 & 2.0129 & & \\
\hline & & $\begin{array}{l}\text { Movement of goods and passenger } \\
\text { train from the original to its } \\
\text { destination station, comfortably, }\end{array}$ & 3.1176 & 3.5674 & & \\
\hline
\end{tabular}




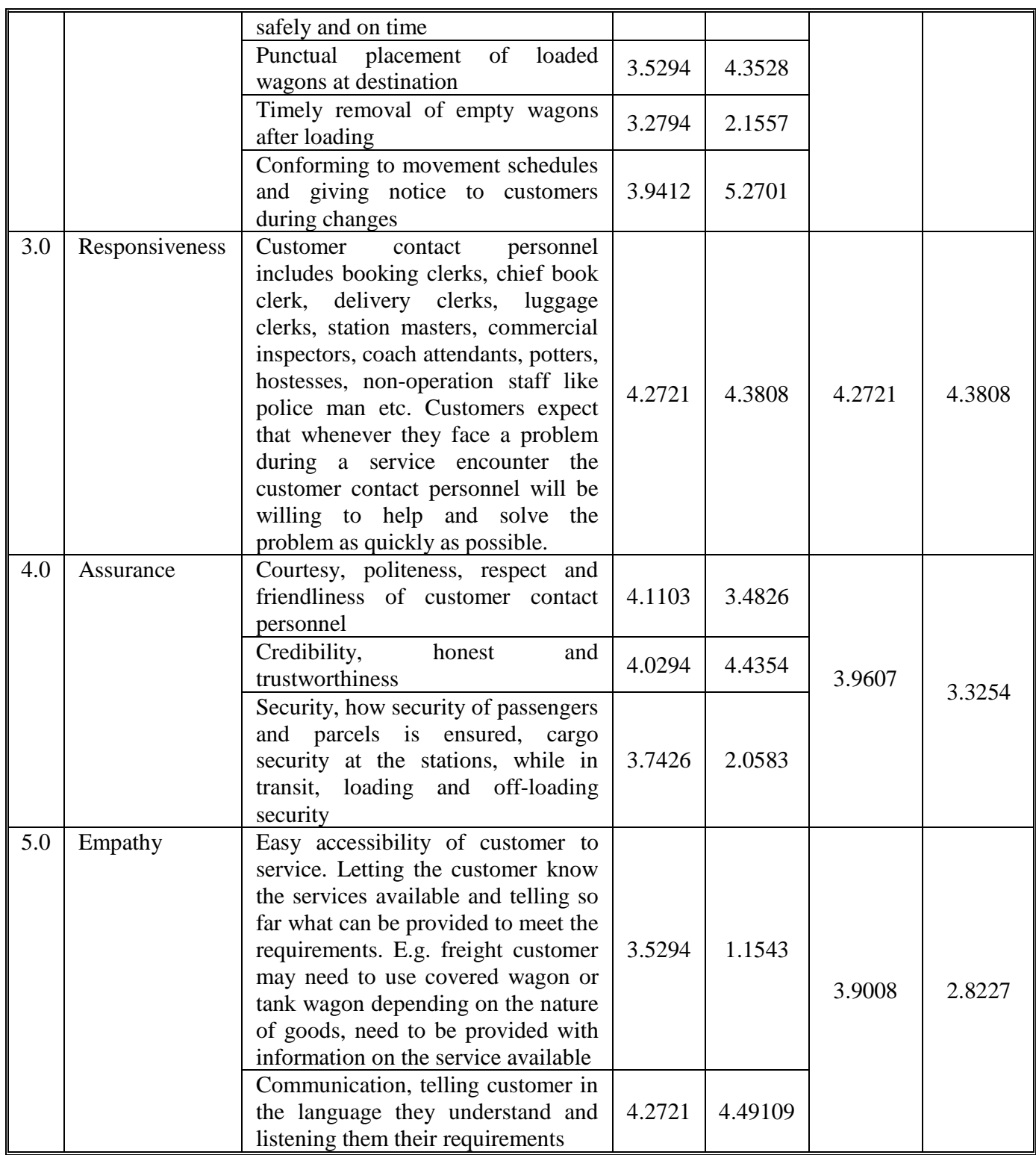

Table 5 shows the statistical descriptions of the dimensions of service quality based on customer satisfaction or dissatisfaction. From the table it is observed that responsiveness recorded the highest mean score of 4.2721 making it the dominant service quality, followed by assurance (mean 3.9607 and standard deviation 3.3254). Tangible became number 3 with mean 3.94485 and standard deviation 0.8979 . The standard deviations are relatively higher, showing the dispersion in a widely spread distribution. However, reliability dimension recorded the lowest mean of 3.3161. This suggests that clients' requirements and queries are accurately predicted along each of the service quality dimension except the reliability dimension. 


\section{Correlation and regression analysis}

\section{Correlation}

The relationship between tangible, reliability, responsiveness, assurance and empathy was examined by Pearson Correlation Coefficient. Correlation is used to interpret whether the relationship of two variables is strong or weak, in terms of the power of relationship and the direction (Pallant, 2001, p.116). The analysis of correlation is derived and shown in table 6.

Table 6. Correlations

\begin{tabular}{|c|c|c|c|c|c|c|}
\hline Dimensions & & Tangibl & Reliability & Responsiveness & Assurance & Empathy \\
\hline \multirow{3}{*}{ Tangible } & Pearson Correlation & 1 & & & & \\
\hline & Sig. (1-tailed) & & & & & \\
\hline & $\mathrm{N}$ & 136 & & & & \\
\hline \multirow{3}{*}{ Reliability } & Pearson Correlation & 0.431 & 1 & & & \\
\hline & Sig. (1-tailed) & 0.001 & & & & \\
\hline & $\mathrm{N}$ & 136 & 136 & & & \\
\hline \multirow{3}{*}{ Responsiveness } & Pearson Correlation & 0.337 & 0.136 & 1 & & \\
\hline & Sig. (1-tailed) & 0.002 & 0.000 & & & \\
\hline & $\mathrm{N}$ & 136 & 136 & 136 & & \\
\hline \multirow{3}{*}{ Assurance } & Pearson Correlation & 0.95 & 0.345 & 0.843 & 1 & \\
\hline & Sig. (1-tailed) & 0.000 & 0.001 & 0.000 & & \\
\hline & $\mathrm{N}$ & 136 & 136 & 136 & 136 & \\
\hline \multirow{3}{*}{ Empathy } & Pearson Correlation & 0.034 & 0.654 & 0.624 & 0.856 & 1 \\
\hline & Sig. (1-tailed) & 0.001 & 0.000 & 0.000 & 0.001 & \\
\hline & $\mathrm{N}$ & 136 & 136 & 136 & 136 & 136 \\
\hline
\end{tabular}

NB: Correlation is significant at the 0.05 level of significance (2-tailed)

Based on the analysis in table 6 , the results show the existence of positive and significant relationship among the service quality dimensions. For example, the relationship between tangible and reliability is positive and significant with correlation coefficient $\mathrm{r}=0.431$ at $\mathrm{p}<0.001$ level. The correlation between reliability and responsiveness, indicates that there is a significant correlation between the two variables with correlation coefficient $r=0.136$ at $\mathrm{P}<0.000$. The correlation between Assurance and Tangible, indicates that there is a significant correlation between the two variables with correlation coefficient $r=0.95$ at $\mathrm{P}<0.000$. Similarly, the correlation between empathy and responsiveness, indicates that there is a significant correlation between the two variables with correlation coefficient $\mathrm{r}=0.624$ at $\mathrm{P}<0.000$.

\section{Multiple regression analysis}

The data collected was regressed by the Statistical Package for Social Science (SPSS). The multiple regression model used in the analysis was as shown below.

Quality service (client satisfaction) $=\beta_{0}+\beta_{1}$ Tangible $+\beta_{2}$ Reliability $+\beta_{3+}$ Responsiveness $+\beta_{4}$ Assurance $_{+} \beta_{5}$ Emphathy $_{+} \varepsilon$

Table 7. Model Summary

\begin{tabular}{|l|l|l|l|l||}
\hline Model & $\mathrm{R}$ & R Square & Adjusted R Square & Std. Error of the Estimate \\
\hline 1 & $0.957 \mathrm{a}$ & 0.915 & 0.909 & 0.30897 \\
\hline
\end{tabular}

a. Predictors: (Constant), Tangibles, Reliability, Responsiveness, Assurance, Empathy

The model summary comes from multiple regression analysis. The result shows that adjusted $\mathrm{R}$ square is 0.90 . This means out of 136 respondents, their perception of quality service 
management accounts for $90 \%$ of total variation in customer service quality satisfaction or dissatisfaction. This means that Tangibles, Reliability, Responsiveness, Assurance, Empathy have a strong relationship.

\section{Analysis of variance (ANOVA)}

Variance analysis (ANOVA), tests the hypothesis in that the means of two or more populations whether are the same or not. ANOVAs assess the significance of one or more factors by comparing the response variable means at different factor levels.

Table 8. Analysis of Variance (ANOVA)

\begin{tabular}{|c|c|c|c|c|c|}
\hline Model & Sum of Squares & Df. & Mean Square & $\mathbf{F}$ & Sig. \\
\hline Regression & 47.273 & & 15.758 & 165.070 & $0.000^{\mathrm{b}}$ \\
\hline 1 Residual & 4.391 & 46 & 0.095 & & \\
\hline Total & 51.664 & 49 & & & \\
\hline
\end{tabular}

Source: Field data (2017)

a. Dependent Variable: Average customer satisfaction

b. Predictors: (Constant), Tangibles, Reliability, Responsiveness, Assurance, Empathy

Table 8 above proves Tangibles, Reliability, Responsiveness, Assurance, Empathy had a significance level of 0.000 (b), hence the model is statistically significant in depicting how a customer service quality management is influenced by the independent variables in this study.

Table 9. Coefficients

\begin{tabular}{||l|c|c|c|c|c|c||}
\hline \multirow{2}{*}{ Model } & \multicolumn{2}{|l|}{ Un-standardized Coefficients } & Standardized Coefficients & T & \multicolumn{2}{l|}{ Sig. } \\
\cline { 2 - 7 } & $\mathrm{B}$ & Std. Error & Beta & & \\
\hline (Constant) & 0.833 & 0.291 & & 2.864 & 0.006 \\
\hline Tangible & 0.804 & 0.088 & 0.807 & 9.106 & 0.000 \\
\hline Reliability & 0.229 & 0.122 & 0.209 & 1.874 & 0.100 \\
\hline Responsiveness & 1.015 & 0.049 & 0.943 & 20.788 & 0.000 \\
\hline Assurance & 0.471 & 0.441 & 0.312 & 5.453 & 0.001 \\
\hline Empathy & 0.612 & 0.236 & 0.403 & 6.986 & 0.000 \\
\hline
\end{tabular}

Dependent variable: Average client satisfaction

In table 9, standardized coefficients indicate how much the dependent variable varies with an independent variable when all other independent variables are held constant. The beta coefficient indicates that how and to what extent SERVQUAL dimensions (Tangibles, Reliability, Responsiveness, Assurance, and Empathy) influence client satisfaction. It has been found that responsiveness $(\beta=0.943, \mathrm{t}=20.788, \mathrm{P}<0.000)$ and Tangible $(\beta=0.807, \mathrm{t}=9.106$, $\mathrm{P}<0.000)$ and empathy $(\beta=0.403, \mathrm{t}=6.986, \mathrm{P}<0.000)$ recorded the highest influence on client satisfaction. However, reliability $(\beta=0.209, \mathrm{t}=1.874, \mathrm{P}<0.100)$ recorded the lowest impact on client satisfaction.

Then the fitted regression model is given as follows;

Overall client satisfaction $(\mathrm{Y})=0.833+0.804$ (Tangible) +0.229 (Reliability) +1.015 (Responsiveness) +0.471 (Assurance) +0.612 (Empathy)

\section{Discussion of Research Findings}

Basing on quality service as gaps identified by Kotler (1997), that cause unsuccessful service delivery, there is the gap between service delivered and external communication of public rail services, this discrepancy in quality of public rail transport service is related to reliability dimension i.e. performance of the promised service accurately and dependably. 
External communication made to customers helps in creating awareness to customers of what is being provided. External communication made through promotional campaigns, advertisements and promises given by service contact personnel, management and their agents are not specifically converted to perceived service which leads to gap 5, where there is a difference between perceived service and expected service and thus customer misperceives service which leads to dissatisfaction.

Gap 1, exists when there is difference between customer expectation and management perceptions, the results suggest that there is no significant difference between customer expectations and management perceptions since marketing research is conducted to identify customer wants and requirements, regular visits to customers offering high volume of traffic are made, communication and regular interaction with customers by service contact personnel help management to capture what the organization is expected of by customers.

Gap 2, exists when there is a difference between management perception and service quality specification, the results suggest that specification, since management does job evaluation, commit resources for quality service, facilitates fast upward communication, levels of management do not hinder communication also service standardization seemed to be acceptable to the customer contact personnel.

Gap 3, exists when there is difference between quality specification and service delivered, the result suggests that there is likelihood of having a significant difference between quality specification and service delivered, in some cases management may understand customers expectations and set appropriate specifications either formally or informally, still however the service delivery fall short of customer expectations, this is experienced when the customer contact personnel are unable, unwilling or may not have the ability to perform the services at desired level. In some cases, service provider may not have the ability to perform the functions properly given that the equipments and facilities are not available.

Internal factor contributing to the difference between external communication and service delivered and hence the difference between perceived service and expected service and ultimately customer dissatisfaction. The results show that customer contact personnel experienced a shortage of working tools; this includes computers, loading equipments, communication tools and other operational facilities. These lag the performance of the promised service accurately and dependably.

\section{Conclusion and recommendations}

The objective of the study was to assess customer service quality management, by taking into account factors affecting quality service so as to be able to track quality and thus highlighting the importance of service quality management in public transport. The study reveals that customers' expectations of service quality are accurately predicted by organizations management along each of the service quality dimensions except the reliability dimension. That is the ability to perform the promised service dependably and accurately. As a result of this management specifies quality standards that fall below customer expectations and hence causes service quality shortfalls.

Managers in service organization often experience difference difficulties in trying to match or exceed customers' expectations. This is due to the factors like some functions require change of organizations system of service delivery to enhance customer perception. This might require altering the process by which the work is accomplished, in some cases change requires new equipments and technology, change also necessitates aligning executives from different part of organization to collectively understand the big picture from the customer point of view, also requires a willingness to be open to different ways of structuring, calibrating and monitoring the provision of service. The study recommends the following: 
- The management should continuously monitor customer satisfaction by carrying market surveys frequently to determine customer requirements, since customer needs and wants keep on changing from time to time and within different age groups, so these surveys should be as frequent as possible, so as to enable to provide the right service the first time.

- The management should incorporate total quality management in the provision of services, so that all departments within organizations are coordinated with the single purpose of satisfying customers, this will instill a marketing orientation establishment among employees and thus proper adherence to the corporate objectives of the organization.

- There should be frequent training sessions or seminars for employees especially the customer contact personnel to update them on current trends in customer requirements and wants; this will enable them to provide the right packaged service to customers consistent to handling their complaints.

- Improving working tools, the organization should ensure that working tools are reliable. In offices there are enough computers, maximizing the operational capacity of equipments by making a review and development of equipments according to the requirements, these will help to improve the internal working environment and thus help an organization to cope with the current situation in the area of technology.

- Assessing what other competitors are doing such as road transport concerning customer expectations. This will help setting quality standards.

- External communication made to customers should be realistic and portray to customers a realistic picture of the service as such promises influence customer expectations and impact on satisfaction.

- The management should commit important resources for quality provision to customers, in doing this management should consider long run benefits.

\section{REFERENCES}

1. Anable, J. (2005). "Complacent car addicts" or "aspiring environmentalist"? Identifying travel behavior segments using attitude theory. Transport Policy, 12(1), 65-78.

2. African Development Bank report (2015). Rail Infrastructure in Africa, Financing Policy Options.

3. Bush, R.P., Hair, J.F., Ortnan, D.J. (2006). Marketing research: Within a changing information environment (3rd ed.). London: McGraw-Hill, Irwin.

4. Carrillat, F.A., Jaramillo, F., Mulki, J.P. (2007). The validity of the SERVQUAL and SERVPERF scales: A meta-analytic view of 17 years of research across five continents. International Journal of Service Industry Management, 18(5), 472-490.

5. Eboli L., Mazzulla G. (2007). Service Quality Attributes Affecting Customer Satisfaction for Bus Transit, University of Calabria.

6. Glynn. W.J and GARMS, J.G (1995). Understanding Service Management. John Wiley. Chichester.

7. Groomnroos, C (1984). A servce quality model and its marketing implications. European Journal of Marketing.

8. Groonroos, C (1990). Service Management and Marketing: Managing the Moment of Truth in service Competition. Lexington, MASS: Lexington Books.

9. Kotler. P (1991). Marketing Management, Planning, Analysis, Implementation and control $7^{\text {th }}$ Ed. Prentice Hall of India private LTD, New Dehhi.

10. Krajewski R. M. (1993). Operations Management, Strategic and Analysis $3^{\text {th }}$ Ed. Addison Wesley.

11. Malcon, H.B et al., (1993), Small Business In Third World Countries, John Wiley and Sons, Cichester. 
12. Nashappi, N. G, Omari S and Nyamonaa, A. R. (2014). Attributes That Influence Customer Satisfaction with Service Quality at Kenya Power Company, International Journal of Innovation Research and Development, vol 3 Issue 4, April, 2014 p 239-247.

13. Oliver, R. L. (1981). Measurement and evaluation of satisfaction process in retail Setting Journal of Retailing, 57(3), 18-48.

14. Olievschi V. N (2013), Railway Transport, Framework for Improving Railway Sector Performance in Sub-Saharan Africa. Africa Transport Policy Program.

15. OECD, (2001). Citizens as Partners: Information, Consultation and Public Participation in Policymaking, Scotland.

16. Parasuraman A, Zeithamal V.A and Berry L.L (1985), A conceptual model of service Quality and its marketing implications for futre research, Journal of Marketing.

17. Ramaswamy, R. (1996). Design and Management of Service Processes: Keeping Customers for Life. Reading, MA: Addison-Wesley Publishing Co.

18. Rasheed F (2016), Impact of Total Quality Management on Customer Satisfaction, International Journal of Management and Commerce Innovations ISSN 2348-7585 (Online) Vol. 4, Issue 2, pp: (702-709).

19. Stanton. W (1994), Fundamentals of Marketing, $6^{\text {th }}$ Ed. McGraw Hill inco U.S.A

20. Internet: www.rim.ed bt/RIM publication/Rigphel 1/Index.htm-8k-

21. http//www.customer expressions.com/CEX web.nsf/menu international open form.

\section{Article history:}

- $\quad$ Received 19 June 2017

- $\quad$ Accepted 29 August 2017 